International Research Journal of Engineering, IT \& Scientific Research
Available online at https://sloap.org/journals/index.php/irjeis/
Vol. 6 No. 2, March 2020, pages: 55-64
ISSN: 2454-2261
http://dx.doi.org/10.21744/irjeis.v0i0.000

\title{
Occupational Safety and Health (OSH) Factors Identified in Indonesian Batik Textile Small/Medium Enterprises
}

\section{Article history:}

Submitted: 09 January 2020

Revised: 18 February 2020

Accepted: 27 March 2020

\section{Keywords:}

batik industry;

health;

OSH;

safety;

small-medium enterprises;

\begin{abstract}
Indonesia is a country with numerous SMEs spread throughout 34 provinces. One of the important problems that need to consent more is labor health and safety. To increase safety, SMEs need to identify factors of occupational health and safety. SMEs need to properly avoid workplace accidents, and the batik industry is no exception. As a first step, it is necessary to identify the OSH factors that can be used in a prevention accident strategy. The population in this study were workers in Indonesia, these batik companies were located in Solo, Yogyakarta, Pekalongan, Cirebon, Minahasa, Bali, Madura, Indramayu, Bengkulu, and Palembang. The questionnaire consisted of latent variables, from the research that has been done, variables that affect work safety are the physical work environment, social work environment, job stress, and work productivity, while the variables that have a significant influence on occupational health are the physical work environment, social work environment, and work stress.
\end{abstract}

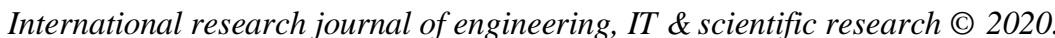

This is an open access article under the CC BY-NC-ND license (https://creativecommons.org/licenses/by-nc-nd/4.0/).

\section{Corresponding author:}

Ayudyah Eka Apsari,

Industrial Engineering Department,

Universitas Islam Batik Surakarta, Indonesia.

Email address: ayudyaheka2511@gmail.com

a Universitas Islam Batik, Surakarta, Indonesia

b Universitas Islam Indonesia, Yogyakarta, Indonesia 


\section{Introduction}

A small industry plays an important role in the economy of Indonesia. The number of micro-, small-, and mediumsized enterprises (SMEs) amounted to 56.6 million with a growth of $2.41 \%$, which, in the crutch workforce, amounted to 107.6 million (Statistic Indonesia, 2016a). Indonesia is a country with numerous SMEs spread throughout 34 provinces. The Java Island has approximately $67.8 \%$ of Indonesian micro- and small businesses, with $28.1 \%$ of these in Central Java $28.1 \%, 22.4 \%$ in East Java, $13.1 \%$ in West Java, 3.2\% in Banten, $1.5 \%$ in Yogyakarta, and $1 \%$ in Jakarta (Statistic Indonesia, 2016b). According to the International Standard Industry Classification (ISIC) codes for the textile industry, Indonesia has 131,433 different types of micro- and small businesses (Statistic Indonesia, 2016c). Meanwhile, small and medium batik industries in Indonesia reached 50,000 units with 100,000 employments (Ministry of Industry, 2016a). The number of workers in the batik industry will certainly be an influence on employment issues (Wisenthige \& Guoping, 2016; Bagudu et al., 2016).

The decline of labor problems has been influenced by several factors. One of them is leader commitment, in which the leader has a relationship with the safety of the workplace (Nielsen et al., 2016). Besides, the organization is classified as a factor that has a significant effect on safety climate (Haslam et al., 2016). To increase safety, SMEs need to identify factors related to occupational health and safety (OSH) (Cagno et al., 2011). Safety conditions in SMEs are worse and less acceptable compared to large enterprises (Cagno et al., 2011; Reinhold et al., 2015). SMEs also have a higher risk of occupational hazards, and their ability to control risk is lower than that of large firms (Jørgensen et al., 2010; Micheli \& Cagno, 2010; Tait \& Walker, 2000).

Based on Jamsostek data, 65,474 accidents happened, which caused 1,451 deaths and 5,326 injuries (Kani, 2013). Accidents should be prevented by identifying accident factors. The information obtained in this study relating to labor (employment, health facilities, health education, health and safety management, and safety activities are important to OSH management (Kongtip et al., 2008). Safety management and safety culture is also an important factor in the prevention of occupational accidents (Jorgensen, 2016).

Efforts to improve the performance of SMEs have been conducted worldwide through the study of knowledge management (Floyde et al., 2013; Chen et al., 2012; Chen et al., 2013), Quality Management System (QMS) certifications (Santos et al., 2013; Santos et al., 2011), and regulation (Deros et al., 2014). The assessment is used to determine the influence of management in how successful SMEs are at anticipating occupational accidents and to encourage investment. Studies indicate that efforts to improve performance have been conducted in several countries. In Indonesia, as a country where SMEs contribute to 57.9\% of GDP (Ministry of Industry, 2016b), investment flows and exports continue to increase (Media Industry, 2015). Thus, SMEs need to properly avoid workplace accidents, and the batik industry is no exception in this regard. Several studies related to batik have been

done. As a first step in reducing the accident rate, it is necessary to identify the OSH factors that can be used in a prevention accident strategy.

\section{Materials and Methods}

\section{Population and Sample}

The population in this study were workers in ten batik companies in Indonesia. These batik companies were located in Solo, Yogyakarta, Pekalongan, Cirebon, Minahasa, Bali, Madura, Indramayu, Bengkulu, and Palembang. The selected batik manufacturers were the most popular in the batik industry (Sindo, 2014). The samples consisted of 400 workers taken at random from each location, such that each location provided 40 samples. The number of samples was estimated using structural equation modeling (SEM) observations of 5-10 for each parameter (Ferdinand 2002; Jogiyanto, 2004). There are 53 parameters used in this study, and therefore the recommended minimum sample size is 265-530. The number of respondents (400) meets this minimum requirement. The locations where the questionnaire was distributed are shown in Figure 1. 


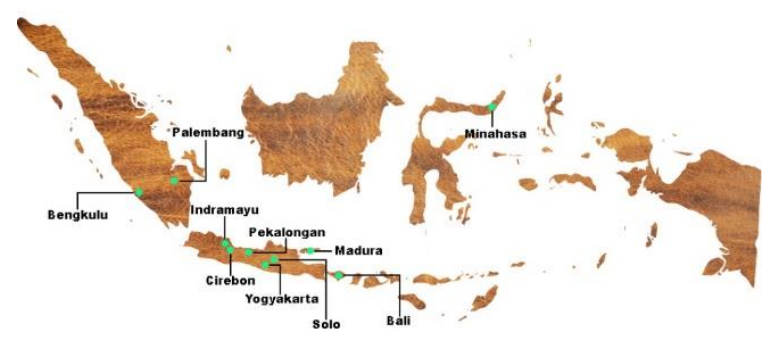

Figure 1. Location of the questionnaire distribution

\section{Questionnaire}

The questionnaire consisted of latent variables, namely occupational safety, occupational health, corporate management, physical work environment, social work environment, work behavior, job stress, and work productivity as a bound variable. The questionnaire used a 5-point Likert scale, with the size of the STD (strongly disagree) score of 1; D (disagree) score of 2; QA (quite agree) score of 3; A (agree) score of 4; SA (strongly agree) score of 5. Details of the variables are as follows:

a) Occupational safety Encompasses OSH training, supervised use of personal protective equipment (PPE), OSH procedures have been implemented, PPE availability, and fire extinguishers.

b) Occupational health

Encompasses stress levels, smoking habits, sleep quality, nutrition and balanced nutrition, sufficient rest, workload, and whether workers relaxed before work.

c) Corporate management

Encompasses the worker's value to the company, whether dangerous work is stopped, whether OSH training is provided if OSH violations are punished, the standard level of satisfaction, and whether there are safety meetings.

d) Physical work environment

Encompasses heat level, air quality, level of noise, available space in work stations, lighting quality, vibration levels, presence or absence of smell, and air humidity.

e) Social work environment

Encompasses the involvement of a social worker in decision making, whether there were awards for workers, the contribution of workers in the running production process, availability or lack of training, availability or lack of supervision, whether there was cooperation among workers, and whether workers cast blame on others.

f) Work behavior

Encompasses the level of accident reporting, whether fellow workers were warned about the dangers and safety, whether materials and tools were in the appropriate place, whether work was performed according to the procedure, and whether instructions were followed.

g) Job stress

Encompasses sleep regularity, appetite, whether a worker could be easily shocked, whether a worker trusted people, whether a worker was easily offended, workers' ability to concentrate, whether workers' were patient in doing all the work and socializing, and quality of social life.

h) Productivity

Encompasses whether tasks were completed on time, adherence to company rules, rate of worker absenteeism, whether workers actively provided input, individual potential, attitude, positive work, and producing on target. 


\section{Research Procedure}

a) Preparation Step

The research procedure began by preparing questionnaires for discussion with stakeholders, including company management, ergonomic experts, and government authorities. The purpose of discussing questionnaires was to allow some companies to provide input and variables that were not included in the questionnaires. Identify industries and labors target in ten regions that are the biggest batik industry in Indonesia

b) Research Step

This research was conducted in the ten most popular batik companies in Indonesia. Respondents were provided with guidance on the purposes and objectives of the study and were asked to fill out questionnaires. A questionnaire distribution was conducted with assistance. The questionnaire distribution was conducted for one month in each of the ten regions for a total of ten months.

c) Analysis of Step

Statistical analysis in this study used Moment Structure Analysis or AMOS version 21. SEM analysis allowed the simultaneous calculation of multiple and interconnected estimated regression equations. The characteristics of this model are as follows: (1) it estimates the relationship of dependent double interlocking, (2) it brings a concept that is not observed in the relationship as well as in determining measurement errors in the estimation process, and (3) it accommodates a set of relationships between the independent variables with the dependent variable and uncovers latent variables (Ghozali, 2008).

\section{Results and Discussions}

Figure 2 shows the result of the confirmatory analysis. 


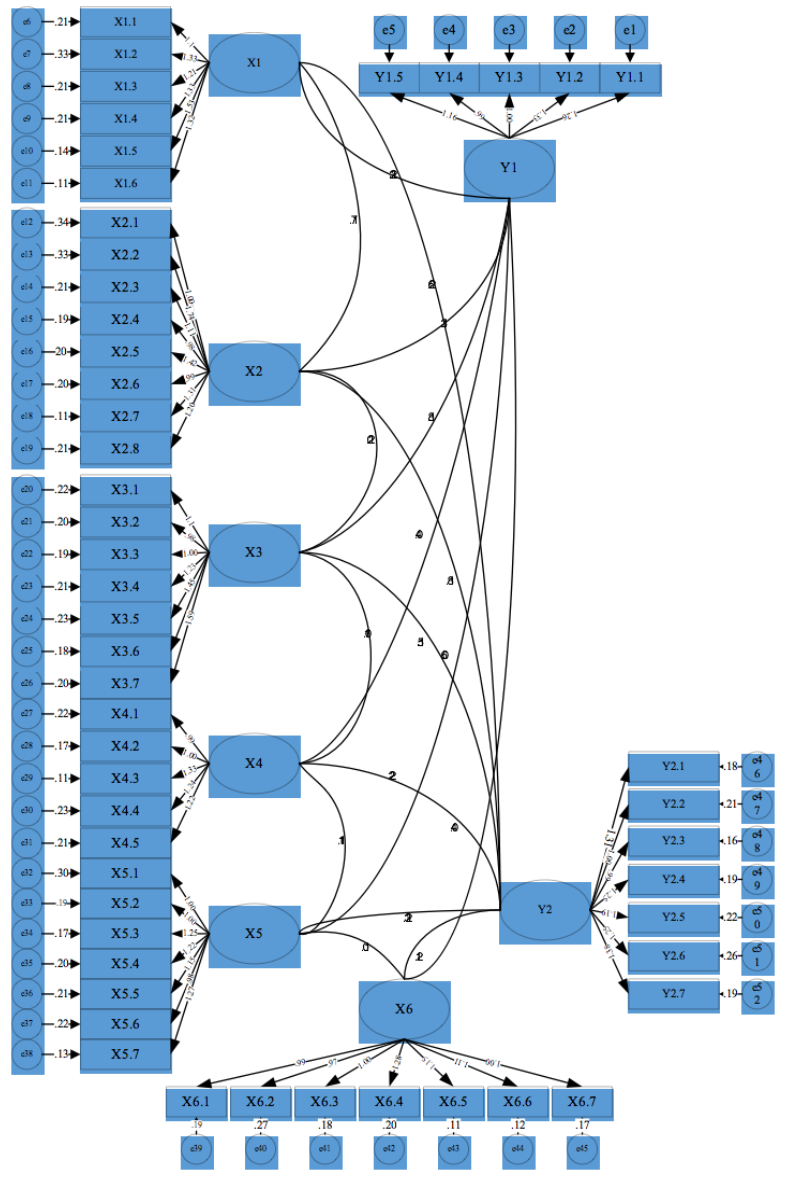

Figure 2. Confirmatory factor analysis

Confirmatory Factor Analysis (CFA) was used to obtain the loading factor estimation, factor weight score, and error variance for each item. The previous figure is the result of CFA in 52 question items from 8 variables, which are as follows: work safety, health, company managerial, physical environment, social environment, work behavior, work stress, and work productivity. The results of the reliability test are shown in Table 1.

Table 1

Reliability test

\begin{tabular}{lll}
\hline Label & Variable & Reliability \\
\hline Y1 & Work Safety & 0.66 \\
Y2 & Health & 0.70 \\
X1 & Company Managerial & 0.66 \\
X2 & Physical Environment & 0.68 \\
X3 & Social Environment & 0.70 \\
X4 & Work Behavior & 0.73 \\
X5 & Work Stress & 0.67 \\
X6 & Work Productivity & 0.71 \\
\hline
\end{tabular}

These results show that the variables have reliability values above 0.5 . Work safety had a value of 0.66 , health had a value of 0.70 , company managerial had a value of 0.66 , the physical environment had a value of 0.68 , the social environment had a value of 0.70 , work behavior had a value of 0.73 , work stress had a value of 0.67 , and work 
productivity had a value of 0.71 . The next step was model testing, whose results are shown in the following figure 3 .

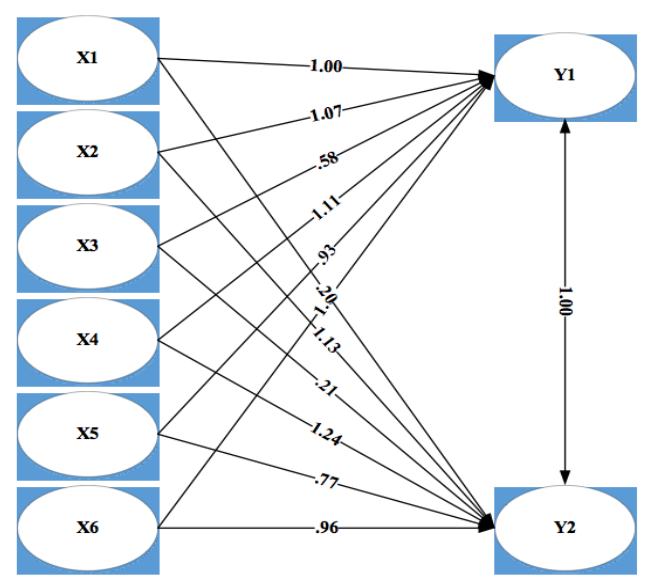

Figure 3. Model testing

An identification test was done to test whether the model could be analyzed further or not. This test used degrees of freedom. SEM could be categorized as:

a) Just Identified Model, which has 0 degrees of freedom and identified, indicating that estimation and model assessment was not necessary.

b) Under-Identified Model, which has <0 (negative) degrees of freedom. The estimation parametric was below variants data and its co-variants, indicating that estimation and model assessment was not necessary.

c) Over-Identified Model, which has $>0$ (positive) degrees of freedom. The estimation parametric was below variants data and its co-variants, indicating that estimation and model assessment was possible to do.

Table 2

Goodness-of-fit model

\begin{tabular}{llll}
\hline $\begin{array}{l}\text { The goodness of Fit } \\
\text { Index }\end{array}$ & Result & Cut Off Value & Criteria \\
\hline Likelihood Chi-Square & 248,734 & Expected to be small & \\
Probability & 0.000 & $\geq 0.05$ & Marginal Fit \\
CMIN/DF & 1.859 & $\leq 2.00$ & Good Fit \\
RMSEA & 0.077 & $\leq 0.08$ & Good Fit \\
GFI & 0.936 & $>0.90$ & Good Fit \\
AGFI & 0.865 & $>0.90$ & Marginal Fit \\
TLI & 0.947 & $\geq 0.90$ & Good Fit \\
CFI & 0.956 & $>0.90$ & Good Fit \\
\hline
\end{tabular}

From the results of the goodness-of-fit index in the preceding table, most of the goodness-of-fit criteria met the cutoff value, and only the probability values and AGFI that do not meet the cut-off value. This is following the opinion of Ghozali (2006), who states that if there are some goodness-of-fit parameters are not qualified, this can be seen from the other parameters, and if the majority of parameters meet the requirements, it can be stated that the model meets the assumption's goodness of fit. The results of the goodness of fit are the value X2 (Chi-Square) with a significance level of 248,734, whereas the minimum sample discrepancy function (CMIN/DF) is an index that measures the relationship of conformity parsimonious goodness-of-fit models and the number of estimated coefficients that are expected to reach the level of conformity. The result of CMIN/DF is 1.859 , which is less than the recommended value CMIN/DF $<2$, thus showing that the model fits well. The root means square error of approximation (RMSEA) is an index which compensates the statistical Chi-Square in huge samples. The RMSEA value indicates the goodness of fit that can be expected when the model is estimated in the population. The recommended value for acceptance is $\leq 0.08$, while the test result is 0.077 , which shows that the model is good.

Based on an analysis of the goodness of fit (GFI), it reflects the level of an overall fitness model. The 
recommended level of acceptance is GFI $>0.90$. The results show that the GFI value is 0.936 , indicating that the model fits well. The Tucker Lewis Index (TLI) is an alternative incremental fit index that compares the baseline models tested. The recommended value of a good fit index is $>0.90$. The results showed that the TLI value was 0.947, so it can be stated that the level of conformity is good. The Comparative Fit Index (CFI) is incremental stability that compares tested models with the null model. The recommended CFI value is $>0.9$. The test results shown 0.956, showing that the model is good.

Table 3

AMOS model estimation result

\begin{tabular}{|c|c|c|c|c|c|c|c|}
\hline \multicolumn{3}{|c|}{$\begin{array}{l}\text { Variables } \\
\text { Relationship }\end{array}$} & \multirow{2}{*}{$\begin{array}{l}\text { Estimate } \\
0.326\end{array}$} & \multirow{2}{*}{$\begin{array}{l}\text { S.E. } \\
0.101\end{array}$} & \multirow{2}{*}{$\begin{array}{l}\text { C.R. } \\
4.069\end{array}$} & \multirow{2}{*}{$\begin{array}{l}\mathrm{p} \\
0.070\end{array}$} & \multirow{2}{*}{$\begin{array}{l}\text { Note } \\
\text { Not significant }\end{array}$} \\
\hline Y1 & $\leftarrow$ & $\mathrm{X} 1$ & & & & & \\
\hline Y1 & $\leftarrow$ & $\mathrm{X} 2$ & 0.198 & 0.082 & 2.136 & 0.031 & Significant \\
\hline Y1 & $\leftarrow$ & $\mathrm{X} 3$ & 0.245 & 0.108 & 2.753 & 0.033 & Significant \\
\hline Y1 & $\leftarrow$ & $\mathrm{X} 4$ & 0.222 & 0.108 & 2.165 & 0.044 & Significant \\
\hline Y1 & $\leftarrow$ & $\mathrm{X} 5$ & 0.211 & 0.100 & 2.176 & 0.015 & Significant \\
\hline Y1 & $\leftarrow$ & X6 & 0.116 & 0.076 & 3.563 & 0.024 & Significant \\
\hline $\mathrm{Y} 2$ & $\leftarrow$ & $\mathrm{X} 1$ & 0.163 & 0.108 & 3.118 & 0.198 & Not significant \\
\hline $\mathrm{Y} 2$ & $\leftarrow$ & $\mathrm{X} 2$ & 0.185 & 0.099 & 2.364 & 0.018 & Significant \\
\hline $\mathrm{Y} 2$ & $\leftarrow$ & $\mathrm{X} 3$ & 0.157 & 0.100 & 4.323 & 0.017 & Significant \\
\hline Y2 & $\leftarrow$ & $\mathrm{X} 4$ & 0.155 & 0.104 & 2.145 & 0.099 & Not significant \\
\hline $\mathrm{Y} 2$ & $\leftarrow$ & $\mathrm{X} 5$ & 0.243 & 0.098 & 1.454 & 0.003 & Significant \\
\hline Y2 & $\leftarrow$ & X6 & 0.154 & 0.078 & 3.638 & 0.067 & Not significant \\
\hline
\end{tabular}

Table 3 shows whether there is a significant relationship between variables or not. This is indicated by a value of significance that is greater than 0.05 . Variables that are not significantly related are as follows: X1 to Y1 (company management to work safety); X1 to Y2 (company management to health) in this case a lot less cares evidenced by the company against exercising their OSH program has been done by Kani et al. (2013), which prove that in Indonesia, the company still has not been given sufficient attention and commitment that is appropriate to implement the OSH program; X4 to Y2 (work behavior with occupational health); X6 to Y2 (productivity with occupational health).

The following variables were shown to be significantly related: X2 to Y1 (physical work environment and work safety) with a $p$-value of 0.031 ; X3 to Y1 (social environment and work safety) with a $p$-value of 0.033 this result is followed by research held by Khan et al. (2014), where the purpose of health and safety, including in fostering a healthy work environment. X4 to Y1 (work behavior with work safety) with a $p$-value of 0.044 ; X5 to Y1 (work stress and work safety) with a $p$-value of 0.015 ; and X6 to Y1 (work productivity and work safety) with a $p$-value of 0.024. Research has been done by Taderera (2012), proving that OSH actions eliminate the hazard or risk and control the hazard at its source by using controls or work processes regularly.

The following variables are related to Y2 (occupational health): X2 to Y2 (physical work environment and occupational health) with a $p$-value of 0.018 , X3 to $\mathrm{Y} 2$ (social work environment with occupational health) with a $p$ value of 0.017 , and X5 to Y2 (work stress and occupational health) with a $p$-value of 0.003 . In terms of occupational health and safety, both the physical and social working environment has a significant influence on health and safety. This conclusion is supported by Grahaningtyas et al. (2012), whose research describes how the working environment physically and psychologically affects health and safety. Furthermore, it also mentioned by ILO (2010), that managerial parties have the overall responsibility in protecting the safety and health of workers. Continuity between all aspects of the possible impact on health and safety, into a single unit for the workers to create a healthy and safe work environment. As previously disclosed by Al-Abdallat et al. (2015), factors in health and safety at work can result in injury and death and can be a burden on society, the economy, families, communities, industry, and government. 


\section{Conclusion}

From the research that has been done, it can be concluded that the variables that affect work safety are the physical work environment, social work environment, job stress, and work productivity, while the variables that have a significant influence on occupational health are the physical work environment, social work environment, and work stress, with $p$ values of $0.018,0.017$, and 0.003 , respectively. Based on the calculations that have been done, work stress (X5) is the most influential factor on the dependent variables. Job stress has a $p$-value of 0.015 against the dependent work safety variable, and a $p$-value of 0.003 against the value of occupational health

\section{Conflict of interest statement}

The authors declared that they have no competing interests.

\section{Statement of authorship}

The authors have a responsibility for the conception and design of the study. The authors have approved the final article.

Acknowledgments

We are grateful to two anonymous reviewers for their valuable comments on the earlier version of this paper. 


\section{References}

Al-Abdallat, E. M., Oqailan, A. M. A., Al Ali, R., Hudaib, A. A., \& Salameh, G. A. (2015). Occupational fatalities in Jordan. Journal of forensic and legal medicine, 29, 25-29. https://doi.org/10.1016/j.jflm.2014.11.001

Bagudu, H. D., Khan, S. J. M., \& Roslan, A.-H. (2016). The impact of microfinance institution on development of small and medium enterprises: a case study of lagos state. International Research Journal of Management, IT and Social Sciences, 3(9), 95-106.

Cagno, E., Micheli, G. J., \& Perotti, S. (2011). Identification of OHS-related factors and interactions among those and OHS performance in SMEs. Safety Science, 49(2), 216-225. https://doi.org/10.1016/j.ssci.2010.08.002

Chen, C. W., Chang, M. L., \& Tseng, C. P. (2012). Retracted: Human factors of knowledge-sharing intention among taiwanese enterprises: A model of hypotheses. Human Factors and Ergonomics in Manufacturing \& Service Industries, 22(4), 362-371. https://doi.org/10.1002/hfm.20286

Chen, C. W., Chang, M. L., Tseng, C. P., Chen, B. C., \& Chang, Y. Y. C. (2013). Retracted: Critical human factor evaluation of knowledge sharing intention in taiwanese enterprises. Human Factors and Ergonomics in Manufacturing \& Service Industries, 23(2), 95-106. https://doi.org/10.1002/hfm.20300

Deros, B. M., Ismail, A. R., Ghani, J. A., \& Yusof, M. Y. M. (2014). Conformity to occupational safety and health regulations in Malaysian small and medium enterprises. American Journal of Applied Sciences, 11(3), $499-504$.

Ferdinand, A. (2002). Structural equation modeling dalam penelitian manajemen. Semarang: Badan Penerbit Universitas Diponegoro.

Floyde, A., Lawson, G., Shalloe, S., Eastgate, R., \& D’Cruz, M. (2013). The design and implementation of knowledge management systems and e-learning for improved occupational health and safety in small to medium sized enterprises. Safety science, 60, 69-76. https://doi.org/10.1016/j.ssci.2013.06.012

Ghozali, I. (2006). Aplikasi Structural Equation Modeling. Metode Alternatif dengan Partial Least Square (PLS), Edisi Pertama, Badan Penerbit Universitas Diponegoro, Semarang.

Ghozali, I. (2008). Struktural Equation Modeling. Teori, Konsep dan Aplikasinya dengan Program Lisrel 8.80. Semarang: Badan Penerbit Undip.

Grahanintyas, D., Wignjosoebroto, S., \& Latiffanti, E. (2012). Analisa Keselamatan dan Kesehatan Kerja (K3) dalam Meningkatkan Produktivitas Kerja (Studi Kasus: Pabrik Teh Wonosari PTPN XII). Jurnal Teknik Pomits, 1(1), 16.

Haslam, C., O’Hara, J., Kazi, A., Twumasi, R., \& Haslam, R. (2016). Proactive occupational safety and health management: Promoting good health and good business. Safety science, 81, 99-108. https://doi.org/10.1016/j.ssci.2015.06.010

ILO. (2010). Guidelines on Occupational Safety and Health Management Systems (ILO-OSH 2001). Safe Work. Geneva: ILO.

Jogiyanto, H. M. (2004). Metodologi Penelitian Bisnis. Yogyakarta: BPFE-UGM.

Jørgensen, K. (2016). Prevention of "simple accidents at work" with major consequences. Safety science, 81, 46-58. https://doi.org/10.1016/j.ssci.2015.01.017

Jørgensen, K., Duijm, N. J., \& Troen, H. (2010). Accident prevention in SME using ORM. Safety science, 48(8), 1036-1043. https://doi.org/10.1016/j.ssci.2010.02.008

Kani, B. R., Mandagi, R. J., p Rantung, J., \& Malingkas, G. Y. (2013). Keselamatan dan Kesehatan Kerja pada Pelaksanaan Proyek Konstruksi (Studi Kasus: Proyek PT. Trakindo Utama). Jurnal Sipil Statik, 1(6).

Khan, N., Choi, J. Y., Nho, E. Y., Jamila, N., Habte, G., Hong, J. H., ... \& Kim, K. S. (2014). Determination of minor and trace elements in aromatic spices by micro-wave assisted digestion and inductively coupled plasma-mass spectrometry. Food chemistry, 158, 200-206. https://doi.org/10.1016/j.foodchem.2014.02.103

Kongtip, P., Yoosook, W., \& Chantanakul, S. (2008). Occupational health and safety management in small and medium-sized enterprises: An overview of the situation in Thailand. Safety Science, 46(9), 1356-1368. https://doi.org/10.1016/j.ssci.2007.09.001

Micheli, G. J., \& Cagno, E. (2010). Dealing with SMEs as a whole in OHS issues: warnings from empirical evidence. Safety science, 48(6), 729-733. https://doi.org/10.1016/j.ssci.2010.02.010

Ministry of Industry, (2016a). Batik Indonesia masih lebih baik. [Online].

Ministry of Industry, (2016b). Pertumbuhan ekonomi dorong ekspansi UKM. [Online].

Nielsen, M. B., Skogstad, A., Matthiesen, S. B., \& Einarsen, S. (2016). The importance of a multidimensional and temporal design in research on leadership and workplace safety. The Leadership Quarterly, 27(1), 142-155. https://doi.org/10.1016/j.leaqua.2015.08.003

Title of manuscript is short and clear, implies research results (Authors) 
Reinhold, K., Järvis, M., \& Tint, P. (2015). Practical tool and procedure for workplace risk assessment: Evidence from SMEs in Estonia. Safety science, 71, 282-291. https://doi.org/10.1016/j.ssci.2014.09.016

Santos, G., Barros, S., Mendes, F., \& Lopes, N. (2013). The main benefits associated with health and safety management systems certification in Portuguese small and medium enterprises post quality management system certification. Safety science, 51(1), 29-36. https://doi.org/10.1016/j.ssci.2012.06.014

Santos, G., Mendes, F., \& Barbosa, J. (2011). Certification and integration of management systems: the experience of Portuguese small and medium enterprises. Journal of cleaner production, 19(17-18), 1965-1974. https://doi.org/10.1016/j.jclepro.2011.06.017

Sindo. (2014). Sepuluh (10) daerah prodosen batik terpopuler. [Online].

Statistic Indonesia. (2016a). Tabel of small and medium enterprises progress period 1997-2012 [Online].

Statistic Indonesia. (2016b). Number of establishments of micro and small manufacturing industry by province 20132015. [Online].

Statistic Indonesia. (2016c). Number of establishments of micro and small manufacturing industry by 2-digit ISIC code 2010-2015. [Online].

Taderera, H. (2012). Occupational health and safety management systems: Institutional and regulatory frameworks in Zimbabwe. International Journal of Human Resource Studies, 2(4), 99.

Tait, R., \& Walker, D. (2000). Marketing health and safety management expertise to small enterprises. Safety science, 36(2), 95-110. https://doi.org/10.1016/S0925-7535(00)00033-3

Wisenthige, K., \& Guoping, C. (2016). Firm level competitiveness of small and medium enterprises (SMEs): analytical framework based on pillars of competitiveness model. International Research Journal of Management, IT and Social Sciences, 3(9), 61-67. 